\title{
Comparative analysis of the influence of climate change and nitrogen deposition on carbon sequestration in forest ecosystems in European Russia: simulation modelling approach
}

\author{
A. S. Komarov and V. N. Shanin \\ Institute of Physicochemical and Biological Problems in Soil Science of the Russian Academy of Sciences, Pushchino, Russia \\ Correspondence to: A. S. Komarov (as_komarov@rambler.ru)
}

Received: 20 April 2012 - Published in Biogeosciences Discuss.: 13 June 2012

Revised: 23 October 2012 - Accepted: 28 October 2012 - Published: 23 November 2012

\begin{abstract}
An individual-based simulation model, EFIMOD, was used to simulate the response of forest ecosystems to climate change and additional nitrogen deposition. The general scheme of the model includes forest growth depending on nitrogen uptake by plants and mineralization of soil organic matter. The mineralization rate is dependent on nitrogen content in litter and forest floor horizons. Three large forest areas in European Central Russia with a total area of about $17000 \mathrm{~km}^{2}$ in distinct environmental conditions were chosen. Simulations were carried out with two climatic scenarios (ambient climate and climate change) and different levels of nitrogen deposition (ambient value and increase by 6 and $12 \mathrm{~kg} \mathrm{Nha}^{-1} \mathrm{yr}^{-1}$ ). The simulations showed that increased nitrogen deposition leads to increased productivity of trees, increased organic matter content in organic soil horizons, and an increased portion of deciduous tree species. For the climate change scenario, the same effects on forest productivity and similar shifts in species composition were predicted but the accumulation of organic matter in soil was decreased.
\end{abstract}

\section{Introduction}

It is well known that nitrogen is a limiting nutrient for tree growth and carbon sequestration in boreal and temperate zones, starting at least from Liebig (1843), and last summaries in Sutton et al. $(2008,2011)$ and Butterbach-Bahl et al. (2011). At first it was widely held that nitrogen deposition should increase tree growth in the Northern Hemisphere (e.g. Townsend et al., 1996). Acceleration of tree growth in Europe has been identified at the end of 1990s (Karjalainen et al., 1999), and the RECOGNITION project has stated ni- trogen deposition as a primary cause of the observed trees growth acceleration (Kahle et al., 2008). Increased nitrogen input through deposition can affect forest ecosystems in different ways. Magnani et al. (2007) found that nitrogen deposition plays a positive role in forest carbon sequestration in boreal and temperate forests. Based on forest inventory data, Thomas et al. (2010) showed that nitrogen deposition within a range of 3 to $11 \mathrm{~kg} \mathrm{ha}^{-1} \mathrm{yr}^{-1}$ increased aboveground biomass by $61 \mathrm{kgC}$ per $\mathrm{kg} \mathrm{N}$ deposited. However, other researchers have shown that increased nitrogen inputs through deposition have almost no effect on carbon sequestration (De Vries et al., 2008; Nadelhoffer et al., 1999). In addition, different tree species may have different responses to nitrogen deposition even in the same region (Thomas et al., 2010). These conflicting results suggest that the effects of nitrogen deposition on carbon sequestration may be regional or sitespecific. At the moment, in some of the temperate forests of central Europe, there is no nitrogen limitation due to nitrogen deposition. In addition, different tree species may have different responses to nitrogen deposition even in the same region (Komarov et al., 2007; Thomas et al., 2010). These facts highlight a need for more research on the various major forest species in the boreal zone. Russian forests are widespread in the northwest and northeast of European Russia, and their response to nitrogen deposition in different climatic zones has not previously been studied. The effects of both climate change and various management options on forest ecosystem dynamics in Central Russia have been studied using simulation modelling (Mikhailov et al., 2004; Palosuo et al., 2008; Verkerk et al., 2006; Shanin et al., 2011, 2012; Zamolodchikov et al., 2008). 
Semi-empirical models (Shvidenko et al., 2007), ROBUL (Zamolodchikov, 2011) and the CBM-CFS3 model (Kurz et al., 2009), have been applied earlier for regional carbon assessment in Russia. They have simulated not individual species but broad functional groups (i.e. deciduous trees, conifers, etc.). Russian forests are represented mostly by mixed stands, and therefore modelling of functional types was not well suited to study the interactions between nitrogen deposition and forest management, which are dependent on species composition. To avoid these issues, an ecosystemlevel individual-based and spatially explicit forest management model is more suitable. Individual-based type of models means that stand is considered as a set of individual trees belonging to different species, and intra- and interspecific competition is calculated directly from shadowing and consuming available nitrogen from corresponding area of nutrition. It gives a possibility of simulating of mixed stands and different kinds of cuttings. The EFIMOD model (Komarov et al., 2003) has been applied in this study.

This model has been used as a management evaluation tool in many types of world forest ecosystems (Chertov et al., 2009; Kahle et al., 2008; Larocque et al., 2008; Shaw et al., 2006). The model is specially designed to examine the impacts of different management strategies or natural disturbance regimes on long-term site productivity and carbon sequestration. A detailed description of the EFIMOD model can be found in Komarov et al. (2003), and a brief description of the algorithms simulating carbon sequestration and nitrogen limitation will be presented in the next section.

Earlier studies have reported both positive and negative responses of soil carbon stock to changing climate. Here we extend studies for the case of different levels of nitrogen deposition and climate changes acting together.

We consider undisturbed development of ecosystems without any management options and natural disasters. In the case of mixed forests, climate change and nitrogen deposition are the main drivers of interspecies competition, which is managing forest growth. How will these drivers supplement each other along climatic gradient at different levels of nitrogen deposition? What factor will be more important, climate or additional nitrogen income (which are both limiting factors in taiga zone)? These are the main questions that we tried to answer with the current study. The main hypothesis that we want to confirm is that both factors acting together have different influence on forest growth and carbon sequestration in forest soils in different climatic zones.

\section{Materials and methods}

\subsection{Model and initialization}

The EFIMOD model (Komarov et al., 2003) being an individual-based type simulates development of tree-soil system. Simulated stand is arranged on a square lattice, and the size of the cells allows only one tree to be located in a cell. The biomass of five compartments (stem, branches, leaves/needles, fine roots, and coarse roots) is calculated for each tree. Forest growth sub-model is linked with the ROMUL model, which describes dynamics of soil carbon and nitrogen (Chertov et al., 2001), and returns available nitrogen for trees growth. There are two types of interactions between trees in a stand: competition for available photosynthetically active radiation (PAR) and competition for soil nitrogen available to plants. Each tree forms a shadow zone and an area of nutrition whose size depends on the tree parameters. There is species-specific reduction for shade-tolerant and intolerant tree species. Areas of nutrition of neighbouring trees overlap, and competition consists of the consumption of different amounts of available nitrogen by fine roots, which are evenly distributed in the tree's area of nutrition. In overlapping areas, available nitrogen is consumed proportionally to the mass of corresponding fine roots. Such description of belowground competition is a considerable distinction from some other models, where competition for light is a main ecosystem driver. It should be noted that, for boreal and partially temperate forests in European Central Russia, which are nitrogen limited, competition for nitrogen (and other elements of nutrition, i.e. basic cations, etc.) has a larger priority than competition for light.

The system of models consists of four main blocks (submodels): (1) a model of individual tree growth; (2) a spatially explicit stand model; (3) a model of soil organic matter (SOM) dynamics, ROMUL; and (4) a statistical climate generator SCLISS which converts climatic variables, including air temperature and precipitation onto the forest floor and soil temperature and moisture, on a monthly basis (Bykhovets and Komarov, 2002).

Each tree compartment is characterized by biomass, nitrogen, and ash contents. Initialization of biomasses is done using Marklund's equations (Marklund, 1988). Biomasses of compartments in the annual modelling step have been calculated using allocation coefficients, which are derived from data on different tree species productivity (Komarov et al., 2003, 2007). Each tree compartment has species-specific nitrogen and ash contents depending on forest site. Thereby, nitrogen turnover has been simulated through corresponding litterfall onto/into soil and the return of available nitrogen from the ROMUL model for tree growth. Nitrogen deposition has been added to the pool of available nitrogen. The flowchart of EFIMOD is shown in Fig. 1.

ROMUL is a model of SOM dynamics based on the assumption that there is a consequent change in the communities of decomposers in the course of SOM decomposition and humification (Chertov et al., 2001). The amount and species composition of decomposers depend on the biochemical properties of organic residues, soil climate, and soil texture. Decomposers (microbes, fungi and soil micro- and mesofauna) produce humic substances, which decompose more slowly. Thus, it is possible to calculate the decomposition 


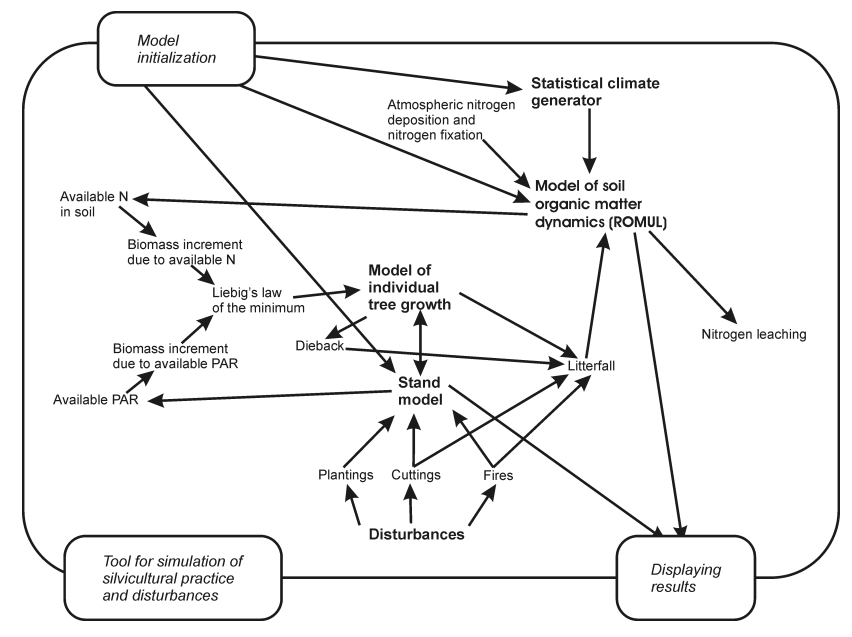

Fig. 1. The flowchart of the EFIMOD model. From Shanin et al. (2012), as subsequently amended.

and humification rates as functions of biochemical properties of litterfall, soil temperature, and moisture.

Nutrients released due to mineralization are absorbed by plants except the situation with strongly shadowed trees. In this case the tree's increment is restricted by light and part of available nitrogen remains unclaimed and goes to nitrogen pool of forest floor. ROMUL describes the dynamics of the three main pools of SOM and corresponding pools of nitrogen: SOM of the forest floor, labile humus of mineral horizons (originating from decomposing root litter), and stable humus of mineral soil consisting of SOM bonded with soil minerals and a slow rate of decomposition. Additionally, ROMUL calculates a pool of mineral nitrogen available for plant nutrition. A simple procedure of leaching of nitrogen from soil to ground water is also included in the model (Chertov et al., 2001). Strong external disasters such as forest fires or clear-cut surplus nitrogen could be spent for leaching and remaining quantity immobilized in forest floor.

Advantages and special features of applications of the individual-based model at regional scale are described in detail in previous publications (Chertov et al., 2006; Shanin et al., 2011, 2012).

The following input parameters are necessary to run the model: the species composition of the mixed forest stand, which consists of forest elements (a "forest element" is an even-aged group of trees of the same species with similar stem heights and diameters); accordingly we need the average height of trees, the average stem diameter at breast height $(\mathrm{DBH})$, the number of trees per hectare, and the age of trees for each forest element.

The characteristics of SOM and N pools have been taken from a special database (Alexeev and Birdsey, 1998; Chestnykh et al., 1999, 2004, 2007; Komarov et al., 2007). Most stand information is available from forest inventory databases. Missing data were calculated on the basis of avail- able data: growing stock, site area, relative stand density, stand composition, site class, and tree species. Missing characteristics of SOM pools have been estimated from two available parameters: forest site class and dominant species in the overstorey, with the use of regional databases and expert estimations (Komarov et al., 2007).

EFIMOD uncertainties and predictions were thoroughly verified against field measurements (Chertov et al., 2003; Mikhailov et al., 2004; Shaw et al., 2006; Kahle et al., 2008; Chertov et al., 2009; Bhatti et al., 2009; Shanin et al., 2011, 2012).

\subsection{Study areas}

Three study areas in different parts of European Russia were chosen for the simulation experiments (Fig. 2). These areas have distinct environmental conditions, soil cover, and vegetation. They were selected to present a latitudinal gradient of climatic conditions. The Dankovskoe forest area (total area $69200 \mathrm{ha}$ ) in the Moscow region consists of middleaged pine and birch stands on weak podzolic soils. The Manturovskoe forest area (180600 ha) in Kostroma region consists of middle-aged pine, birch, and aspen stands as the most common species. Soil cover is formed by sandy and loamy-sandy, podzolic, sod-podzolic, and peaty-gley soils, with an underlying moraine. The Zheleznodorozhnoe forest area (in the Komi Republic), with an area of about 1445000 ha, consists of young and old-growth stands; the prevailing tree species are Norway spruce (Picea abies (L.) Karst.) and Scots pine (Pinus sylvestris L.). Soil cover is presented by podzolic, swamp-podzolic, and peat-bog soils (Zaboeva, 1975). Annual average temperature varies from $5.0^{\circ} \mathrm{C}$ in the Moscow region to $0.1^{\circ} \mathrm{C}$ in the Komi Republic $\left(3.0^{\circ} \mathrm{C}\right.$ in the Kostroma region); annual total precipitation is $634 \mathrm{~mm}$ in the Dankovskoe forest area, $621 \mathrm{~mm}$ in the Manturovskoe forest area, and $585 \mathrm{~mm}$ in the Zheleznodorozhnoe forest area.

Forest datasets consist of many thousands records of individual stands (forest compartments), which were parcelled out during forest inventory. Such an approach allows for estimating the dynamics of a whole territory and for identifying certain general trends, and it makes possible the detailed comparative analysis. The disadvantage of such an approach is its laboriousness, because many initial parameters should be entered to perform the model experiment at the certain scenario for each stand.

Therefore the following procedure of forest inventory data generalization has been developed (Shanin et al., 2011). All records in the database were grouped in relation to standdominant species, the dominant age group and forest site type. Further a generalization of the forest compartment characteristics was done for each group. All stand areas for the group were summarized. For some characteristics like yield class, relative stand density and growing stock, the area-weighted average values were calculated. Portion of 


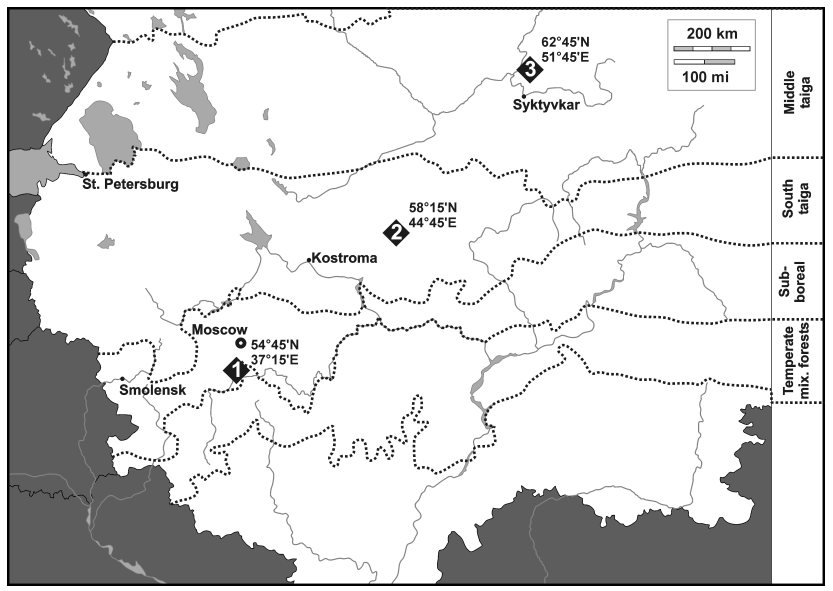

Fig. 2. Areas under study: 1 - Dankovskoe forest area; 2 - Manturovskoe forest area; 3 - Zheleznodorozhnoe forest area. Dashed lines delineate approximate borders of vegetation subzones. Geographic coordinates for the CRU TS 2.0 dataset grid box closest to the corresponding area under study are shown. Based on a map by Daniel Dalet (d-maps.com). From Shanin et al. (2012), as subsequently amended.

each tree species within the group and weighted size characteristics were calculated also. The procedure allows for application of individual-based model at regional level.

Forest site classification of edaphic forest sites used in Russian forest management is based on two factors: soil richness and moisture (Vorobjev, 1953). The soil richness series consists of four grades, from A to D, in increasing order of soil fertility. Additionally, there are six grades of moisture from very dry sites (with index 0 ) to forest and open bogs (index 5). When these two measures are combined, the resulting index of forest site type can be obtained. For example, a forest site A3 refers to a relatively moist site with forest site soil. Every forest site unit has a set of forest types with forest vegetation of different stand, underbrush and herbaceous layer composition as succession stages after various disturbances. The occurrence of different forest sites in areas under study, as well as their basic characteristics in terms of soil richness and moisture, is given in Tables 1 and 2. Dry and moderately wet sites with relatively rich soil prevail in the Dankovskoe forest area, while in the Manturovskoe and Zheleznodorozhnoe forest areas a considerable part of the total area is covered by habitats with lean soils. Also, the Zheleznodorozhnoe forest area is characterized by excessive moisture in nearly the entire territory. As such, distinct dynamics of forest ecosystems can be expected in these areas. Modelling at these three areas with different climatic conditions will allow us to construct a latitude transect and to extrapolate the results of these simulations to larger areas.
Table 1. Initial distribution of different forest sites and some their characteristics. Occurrence means the portion of total area that is covered by the certain forest site, for Dankovskoe (D), Manturovskoe (M) and Zheleznodorozhnoe (Z) forest area. Dominant species means the species occurring on certain forest site: A Eurasian aspen (Populus tremula L.), B - silver birch (Betula pendula Roth), $\mathrm{P}$ - Scots pine (Pinus sylvestris L.), S - Norway spruce (Picea abies L.), L - small-leaved lime (Tilia cordata Mill.), O pedunculate oak (Quercus robur L.). Data on moisture were taken from simulated scenarios.

\begin{tabular}{lrrrllll}
\hline & \multicolumn{3}{c}{ Occurrence (\%) } & & \multicolumn{2}{l}{ Moisture (vol. \%) } \\
\cline { 2 - 3 } \cline { 7 - 8 } $\begin{array}{l}\text { Forest } \\
\text { site }\end{array}$ & $\mathrm{D}$ & $\mathrm{M}$ & $\mathrm{Z}$ & $\begin{array}{l}\text { Dominant } \\
\text { species }\end{array}$ & $\begin{array}{l}\text { Forest } \\
\text { floor }\end{array}$ & $\begin{array}{l}\text { Mineral } \\
\text { soil }\end{array}$ \\
\hline A0 & - & $<0.01$ & - & $\mathrm{P}$ & 6 & 25 \\
A1 & 0.08 & 2.14 & 2.45 & B,P,S & $6-12$ & $14-25$ \\
A2 & 3.32 & 6.44 & 3.84 & B,P,S & $10-12$ & $23-30$ \\
A3 & - & 14.89 & 0 & A,B,P,S & 15 & 40 \\
A4 & 0.03 & 4.82 & - & P & 26 & 52 \\
A5 & 0.09 & 1.03 & - & B & 26 & 52 \\
B2 & 11.73 & 4.47 & - & A,B,P,S,L,O & $10-12$ & $23-30$ \\
B3 & 16.23 & 44.95 & 20.47 & A,B,P,S,L,O & $12-26$ & $25-52$ \\
B4 & 0.76 & 3.95 & 51.09 & A,B,P,S & $15-26$ & $30-52$ \\
B5 & - & 0.77 & 21.79 & B,P,S & $15-26$ & $30-52$ \\
C2 & 36.41 & 1.12 & 0.36 & A,B,P,S,L,O & $10-12$ & $23-30$ \\
C3 & 28.5 & 8.39 & - & A,B,P,S,L,O & $12-26$ & $40-52$ \\
C4 & 2.51 & 6.37 & - & A,B,S & 26 & 52 \\
C5 & 0.02 & 0.66 & - & A & 26 & 52 \\
D3 & 0.32 & - & - & O & 26 & 52 \\
\hline
\end{tabular}

\subsection{Management and climate scenarios}

Simulations were done for $100 \mathrm{yr}$ starting in the 1990s using corresponding forest inventory data for all stands of the case studies. The forest growth scenario without any silvicultural operations was used for the simulations. It assumed that tree stands in all case studies are conserved as a forest reserve. The natural regeneration was modelled every $15 \mathrm{yr}$ in the specific proportions of the tree species depending on the forest site types and dominant trees (Shanin et al., 2011). The density after regeneration was 2000 trees ha $^{-1}$.

Two climatic scenarios were designed using statistical simulator SCLISS (Bykhovets and Komarov, 2002): _S, based on contemporary climate, and "catastrophic climate change" (_C) using HadCM3 model and A1Fi emission scenario.

For the scenario with a contemporary climate $\_$, the input climatic parameters for SCLISS have been estimated on the basis of the set of climatic scenarios compiled by Mitchell et al. (2004) which are available at the Climate Research Unit of the University of East Anglia website (http: //www.cru.uea.ac.uk/cru/data/hrg.htm). This set includes a gridded $\left(0.5^{\circ} \times 0.5^{\circ}\right)$ climatic dataset for the 20th century, CRU TS 2.0, and a set of climate change scenarios for the 21 st century, TYN SC 2.0. It should be noted that simulated by SCLISS monthly air temperature and precipitation have 
Table 2. Variation in characteristics of soil for different forest sites. Values on organic matter and nitrogen pools are obtained from special database (Chestnykh et al., 1999, 2004, 2007) and used for the initialization of the ROMUL sub-model of soil organic matter dynamics. These amounts are also influenced by species composition in overstorey and geographical location.

\begin{tabular}{|c|c|c|c|c|c|c|}
\hline & \multicolumn{2}{|c|}{ Forest floor $\left(\mathrm{Mg} \mathrm{ha}^{-1}\right)$} & \multicolumn{2}{|c|}{ Labile humus $\left(\mathrm{Mg} \mathrm{ha}^{-1}\right)$} & \multicolumn{2}{|c|}{ Humus $\left(\mathrm{Mg} \mathrm{ha}^{-1}\right)$} \\
\hline & SOM & $\mathrm{N}$ & SOM & $\mathrm{N}$ & SOM & $\mathrm{N}$ \\
\hline \multicolumn{7}{|l|}{ Forest site } \\
\hline A0 & 8.9 & 0.13 & 18.5 & 0.14 & 65.5 & 6.63 \\
\hline A1 & $2.7-9.7$ & $0.02-0.12$ & $6.8-23$ & $0.01-0.3$ & $25.4-144.4$ & $1.12-11.02$ \\
\hline $\mathrm{A} 2$ & $3.1-10.6$ & $0.05-0.14$ & $3.3-27.6$ & $0.009-0.45$ & $41.6-153.9$ & $1.83-11.91$ \\
\hline A3 & $0.5-11.5$ & $0.05-0.12$ & $8.5-32.1$ & $0.045-0.18$ & $113.9-163.4$ & $6.41-11.91$ \\
\hline A4 & 133.0 & 2.37 & 38.5 & 0.69 & 71.5 & 2.55 \\
\hline A5 & 117.7 & 1.89 & 11.0 & 0.195 & 99.0 & 3.54 \\
\hline B2 & $3.7-11.5$ & $0.06-0.18$ & $7.5-32.1$ & $0.07-0.56$ & $48.6-178.6$ & $2.07-12.40$ \\
\hline B3 & $3.3-20$ & $0.04-0.48$ & $6.1-46.2$ & $0.013-0.9$ & $85.8-195.7$ & $3.35-13.68$ \\
\hline B4 & $15.2-51.7$ & $0.19-1.44$ & $7.6-71$ & $0.031-0.96$ & $60.0-182.7$ & $3.55-4.91$ \\
\hline B5 & $4.8-6.6$ & $0.16-0.23$ & $4.2-14.8$ & $0.014-0.049$ & 82.8 & 3.47 \\
\hline $\mathrm{C} 2$ & $3.4-10.1$ & $0.04-0.15$ & $5.7-36$ & $0.006-0.99$ & $67.0-212.8$ & $3.71-14.64$ \\
\hline $\mathrm{C} 3$ & $3.9-16$ & $0.05-0.4$ & $8.1-45.8$ & $0.05-0.99$ & $81.9-228.0$ & $3.65-15.35$ \\
\hline $\mathrm{C} 4$ & 26.3 & 1.17 & $23.2-69.6$ & $0.57-1.7$ & $162.4-208.8$ & $7.93-10.2$ \\
\hline $\mathrm{C} 5$ & 26.3 & 1.17 & 23.2 & 0.57 & 208.8 & 10.2 \\
\hline D3 & 05.7 & 0.13 & 20.3 & 0.61 & 182.7 & 10.9 \\
\hline \multicolumn{7}{|c|}{ Forest area under study } \\
\hline Dankovskoe & 32.3 & 0.61 & 21.5 & 0.84 & 96.7 & 4.57 \\
\hline Manturovskoe & 28.9 & 0.68 & 19.7 & 0.23 & 149.2 & 10.24 \\
\hline Zheleznodorozhnoe & 29.4 & 0.45 & 19.1 & 0.13 & 71.2 & 4.28 \\
\hline
\end{tabular}

the same statistical characteristics as measured ones in the mentioned dataset including monthly and annual variations.

The _C scenario from 2001 to 2100 was chosen as the most "extreme" scenario of warming to show the widest range of possible climatic conditions. It was based on the HadCM3 model and the A1Fi emission scenario. According to the scenario, average annual air temperature increases by $7.4^{\circ} \mathrm{C}$ in the Dankovskoe forest area, by $7.2^{\circ} \mathrm{C}$ in the Manturovskoe forest area, and by $7.3^{\circ} \mathrm{C}$ in the Zheleznodorozhnoe forest area. Corresponding total changes in precipitation are not so remarkable: $-1 \%$ in the Dankovskoe forest area, $8 \%$ in the Manturovskoe forest area, and $5 \%$ in the Zheleznodorozhnoe forest area), mostly due to the increased monthly totals in winter. Both scenarios were taken for the dataset grid boxes, which were the closest to the study areas.

\subsection{Nitrogen deposition scenarios}

To assess the effect of additional nitrogen on forest ecosystems, three levels of nitrogen deposition were proposed. The ambient level was taken as a baseline. It was $13.2 \mathrm{~kg} \mathrm{Nha}^{-1} \mathrm{yr}^{-1}$ for Dankovskoe forest area, $7.2 \mathrm{~kg} \mathrm{Nha}^{-1} \mathrm{yr}^{-1}$ for Manturovskoe forest area, and $4.8 \mathrm{~kg} \mathrm{~N} \mathrm{ha}^{-1} \mathrm{yr}^{-1}$ for Zheleznodorozhnoe forest area (State report, 1998, 2011). We also used two levels of probable increases in nitrogen inputs. The first one assumed an increase in deposition by $6 \mathrm{~kg} \mathrm{Nha}^{-1} \mathrm{yr}^{-1}$ in comparison to the ambient level, and the second simulated an increase by $12 \mathrm{~kg} \mathrm{Nha}^{-1} \mathrm{yr}^{-1}$. Such scenarios were first proposed for Manturovskoe forest area as two- and three-fold increases in ambient atmospheric inputs and were then used for all areas under study to keep the same values of absolute increase.

\section{Results}

The increase in nitrogen input with atmospheric precipitation resulted in a predicted increase in the productivity of stands (Fig. 3). It led to increased litter production and to a higher rate of SOM decomposition and corresponding carbon dioxide emission. Climate change also resulted in productivity gain and in an increase in rate of decomposition in the soil. This, on the one hand, led to an increase in the release of inorganic nitrogen compounds, which are available for plants, and resulted in a productivity gain. But, on the other hand, the increased rate of mineralization negatively affected the accumulation of carbon, which was calculated as net primary production (NPP) minus soil hetretrophic respiration. As a result, the accumulation of carbon at the climate change scenario was almost equal to or even lower (for Dankovskoe forest area, Fig. 3a) than under an ambient climate for all levels of nitrogen deposition. Comparison of the simulation results for 100-yr simulations for the different areas under study shows that net primary production 


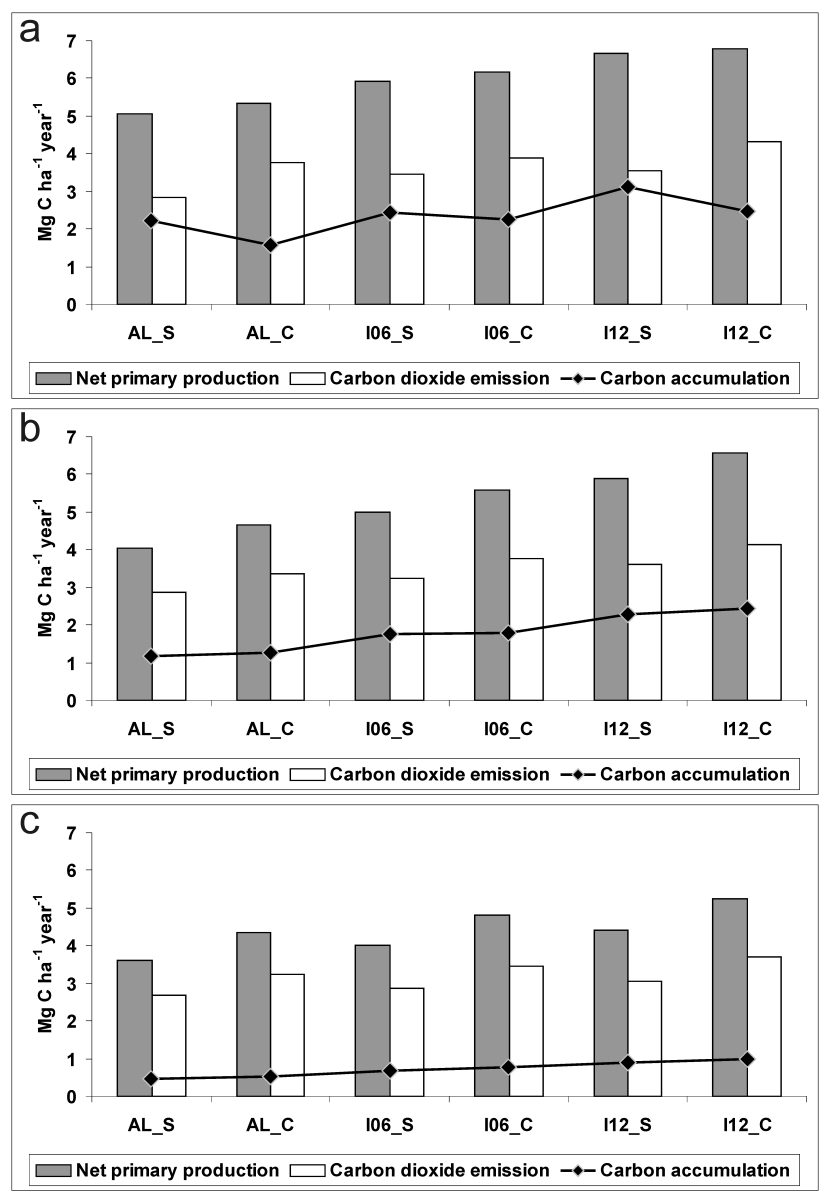

Fig. 3. Average values of NPP, emission of $\mathrm{CO}_{2}$, and accumulation of carbon with different levels of deposition of nitrogen compounds (AL - ambient level, I06 - increase of $6 \mathrm{~kg}[\mathrm{~N}] \mathrm{ha}^{-1} \mathrm{yr}^{-1}, \mathrm{I} 12$ increase of $12 \mathrm{~kg}[\mathrm{~N}] \mathrm{ha}^{-1} \mathrm{yr}^{-1}$ ) and climatic scenarios (_S - ambient climate, $\mathrm{C}$ - climate change) for the different areas under study ((a)-Dankovskoe forest area, (b) - Manturovskoe forest area, (c) Zheleznodorozhnoe forest area).

decreased from south (Dankovskoe forest area at ambient climate of $5.99 \mathrm{MgC} \mathrm{ha}^{-1} \mathrm{yr}^{-1}$ ) to north (Zheleznodorozhnoe forest area, $4.41 \mathrm{MgC} \mathrm{ha}^{-1} \mathrm{yr}^{-1}$ ). The average value of NPP in Manturovskoe forest area was $5.29 \mathrm{MgCha}^{-1} \mathrm{yr}^{-1}$. Soil heteretrophic respiration for different sites was quite similar for all regions (3.64 Mg Cha $\mathrm{Mr}^{-1}$ in Dankovskoe forest area, $3.50 \mathrm{MgC} \mathrm{ha}^{-1} \mathrm{yr}^{-1}$ in Manturovskoe forest area, and 3.16 $\mathrm{MgC} \mathrm{ha}^{-1} \mathrm{yr}^{-1}$ in Zheleznodorozhnoe forest area), and accumulation of carbon was $2.35 \mathrm{MgCha}^{-1} \mathrm{yr}^{-1}$ in Dankovskoe forest area, $1.79 \mathrm{MgCha}^{-1} \mathrm{yr}^{-1}$ in Manturovskoe forest area, and $0.72 \mathrm{Mg} \mathrm{Cha}^{-1} \mathrm{yr}^{-1}$ in Zheleznodorozhnoe forest area.

As a result, maximum accumulation of carbon in the ecosystems took place in south, and minimal in north. This trend was similar for all scenarios of climate change and nitrogen deposition, but absolute values were different and in- creasing for scenarios with climate change and different levels of nitrogen deposition (Fig. 3).

The relative carbon accumulation was dependent on forest site, being in the interval of $30-100 \mathrm{~kg} \mathrm{Cha}^{-1} \mathrm{yr}^{-1}$ per $1 \mathrm{~kg} \mathrm{~N} \mathrm{ha}^{-1} \mathrm{yr}^{-1}$ for the scenario of ambient climate and ambient nitrogen deposition.

Carbon stock in soil by the end of simulation period at ambient climate and ambient level of nitrogen deposition (AL_S) was equal to $89.1 \mathrm{MgCha}^{-1}$ in Dankovskoe forest area, $100.1 \mathrm{MgC} \mathrm{ha}^{-1}$ in Manturovskoe forest area, and $62.5 \mathrm{Mg} \mathrm{Cha}^{-1}$ in Zheleznodorozhnoe forest area while initial values were $75.3,98.9$, and $59.9 \mathrm{Mg} \mathrm{Cha}^{-1}$, correspondingly. Additional nitrogen income resulted in $7-11 \%$ higher soil carbon stock while climate change resulted in 10-20\% decrease, in comparison to ambient climate. The proportion of forest floor in total SOM stock was 10-20\%. It should also be noted that differences between outputs at different climatic scenarios in terms of both total carbon stock in soil and proportions of different SOM fractions were most remarkable for the more southern Dankovskoe forest area (Fig. 4a) and least remarkable for the northern Zheleznodorozhnoe forest area (Fig. 4c). The effect of increasing nitrogen deposition on the changes in the total carbon stock in soil and the proportion of organic layer in different areas showed a similar pattern: the increase was more remarkable in Dankovskoe and Manturovskoe forest areas in comparison with Zheleznodorozhnoe forest area.

The total nitrogen stock in an ecosystem increased with increasing nitrogen deposition (Fig. 5). The dynamics of different pools of nitrogen were closely related to the dynamics of corresponding carbon pools (soil, stand, coarse organic debris). Both climate change and increased nitrogen deposition resulted in the increase of the amount of available nitrogen. The nitrogen pool in tree biomass grew, and the nitrogen pool in soil fell correspondingly.

To describe the effects of warming and nitrogen deposition on the dynamics of species composition, we split all tree species into three groups. The first group consists of so-called parvifoliate tree species, which are pioneer species with fast growth and high demand for nutrients: silver birch (Betula pendula Roth) and European aspen (Populus tremula L.). The second group includes small-leaved lime (Tilia cordata Mill.) and pedunculate oak (Quercus robur L.), which are tolerant species with highly competitive capacities, which also require fertile soil but have lower metabolic rates than the previous group. Both groups are rich in nitrogen contents in compartments. The third group includes coniferous species whose needs for soil nutrition are lower than those of parvifoliate and broadleaved species: Norway spruce (Picea abies (L.) H. Karst.) and Scots pine (Pinus sylvestris L.).

The increase in nitrogen deposition led to increasing portions of parvifoliate and broadleaved tree species, which require more nutrients for growth than coniferous species. The effect of climate change was generally the same but with some exceptions. The effect of nitrogen deposition on 


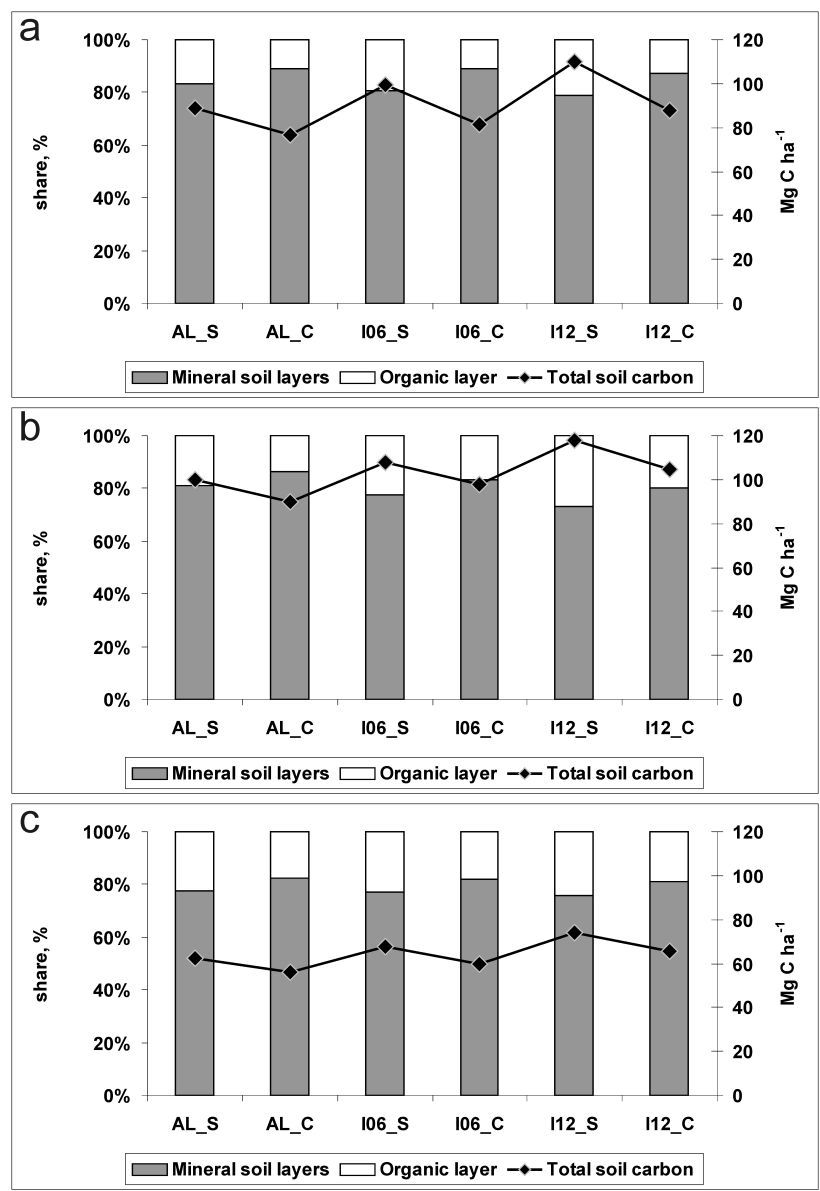

Fig. 4. Proportions of different SOM fractions and total carbon stock in soil by the end of simulation with different levels of nitrogen deposition (AL - ambient level, I06 - increase of

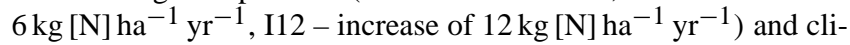
matic scenarios ( $\mathrm{S}$ - ambient climate, $\mathrm{C}$ - climate change) for the different areas under study ((a) - Dankovskoe forest area, (b) Manturovskoe forest area, (c) - Zheleznodorozhnoe forest area).

species composition was the most remarkable in the warmer Dankovskoe forest area. The territory of Zheleznodorozhnoe forest area is beyond the geographic range of broadleaved tree species; the relative increase in the share of parvifoliate species in this case was rather low.

\section{Discussion}

\subsection{Carbon accumulation}

Further we consider and compare preliminary simulation results on carbon accumulation in relation to three different factors: (1) climatic zone expressed in the model by temperature, precipitation and distribution of forest sites; (2) climate changes; and (3) different levels of nitrogen deposition.

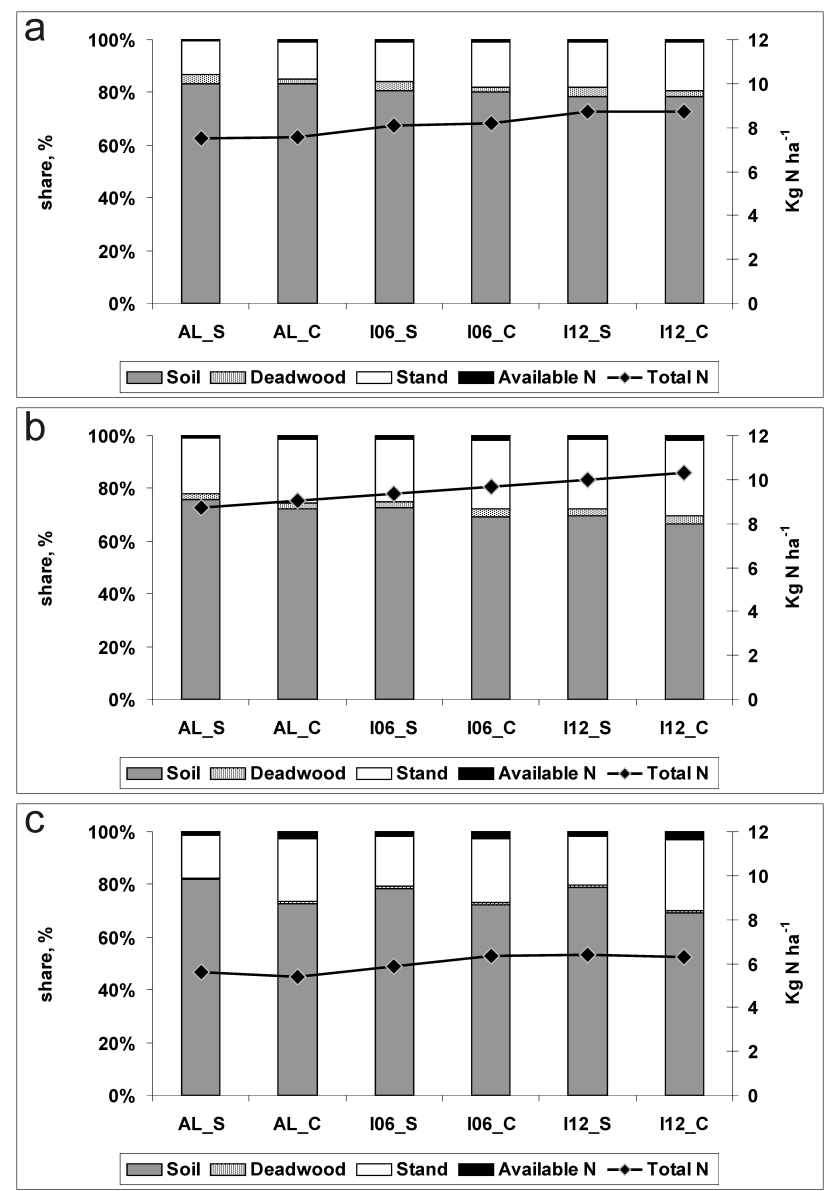

Fig. 5. Nitrogen stocks in different pools by the end of simulation with different levels of deposition of nitrogen compounds (AL ambient level, I06 - increase of $6 \mathrm{~kg}[\mathrm{~N}] \mathrm{ha}^{-1} \mathrm{yr}^{-1}, \mathrm{I} 12$ - increase of $12 \mathrm{~kg}[\mathrm{~N}] \mathrm{ha}^{-1} \mathrm{yr}^{-1}$ ) and climatic scenarios ( $\mathrm{S}-$ ambient climate, _C - climate change) for the different areas under study ((a) - Dankovskoe forest area, (b) - Manturovskoe forest area, (c) Zheleznodorozhnoe forest area).

\subsubsection{Geographical trends}

Results of our study showed that NPP decreased from south to north (Fig. 3). Simulated NPP values (3.6$5.1 \mathrm{MgC} \mathrm{ha}^{-1} \mathrm{yr}^{-1}$ ) were in a good accordance with known data from literature. Values of NPP for European transect (6.3-16.7 $\mathrm{MgC} \mathrm{ha}^{-1} \mathrm{yr}^{-1}$ ) are higher (Schulze, 2000), but they are measured for more southern and warmer territories in Europe. Our results are close to data on Enissei transect in Siberia (3.0-5.4 $\mathrm{MgC} \mathrm{ha}^{-1} \mathrm{yr}^{-1}$ ) (Bazilevich and Titlyanova, 2008) and 3.5-6.0 $\mathrm{Mg} \mathrm{Cha}^{-1} \mathrm{yr}^{-1}$ for northern hardwoods (Cannell, 1982; Melillo et al., 1993). Average values of soil $\mathrm{CO}_{2}$ emission are in a range of measured data for European Central and northern Russia (Kurganova et al., 2003).

Maximum accumulation of carbon in the ecosystem takes place in south, and minimal in north. This trend is similar for 
all scenarios of climate change and nitrogen deposition. Absolute values increased with warming and increasing level of nitrogen deposition except southern site where warming decreases accumulation at all levels of nitrogen deposition (Fig. 3). For intermediate and northern sites, influence of climate changes expressed in biomass is lower than influence of additional nitrogen.

\subsubsection{Effect of climate change and nitrogen deposition}

A positive effect of climate change on forest productivity, particularly for boreal forests of the Northern Hemisphere, was noted in many studies (Lopatin et al., 2006; Myneni et al., 1997; Spiecker et al., 1999; Komarov et al., 2007; Kahle et al., 2008). Authors usually mention two possible sources of positive influence: (1) increased carbon dioxide concentration and temperature (Boisvenue and Running, 2006; Cole et al., 2010; Coops and Waring, 2001; Ellsworth et al., 2012; Moore et al., 2006) and (2) increased input of nitrogen compounds with precipitation (Callahan et al., 2008; Högberg, 2012; Vetter et al., 2005). Some authors showed that warming may stimulate decomposition of soil organic matter (Kirschbaum, 1994; Lloyd and Taylor, 1994; Bhatti et al., 2009). Consequently, enhanced decomposition of SOM also increases nutrient availability and stimulates forest productivity (Melillo et al., 1993).

In our computer experiments, warming resulted in increase of heterotrophic respiration due to increased rate of decomposition of dead organic matter in soil. Such an increase led to additional release of nitrogen compounds and, in turn, to increased NPP at scenarios of climate change (Fig. 3 and Table 3).

An increase in nitrogen deposition from the atmosphere for Northern Hemisphere leads to a couple of opposite consequences. The first one is an increase in forest growth and possible corresponding increase in litter flow to soil. Also, it is known that, in temperate forest soils where nitrogen does not limit microbial growth, nitrogen deposition could impede the decomposition of organic matter and thus stimulate carbon sequestration (Janssens et al., 2010; Ramirez et al., 2010). At the same time, an increase of forest floor temperature due to climate change also leads to higher rates of SOM decomposition (Rustad et al., 2001; Vetter et al., 2005). However the inhibition of decomposition processes due to nitrogen fertilization or both positive and negative responses to increased nitrogen supply have been reported in some studies (e.g. Johnson and Curtis, 2001; Pussinen et al., 2002; Prescott, 1995; Knorr et al., 2005).

The analysis of results will be clearer if we calculate the values of relative carbon accumulation, in terms of kilograms of carbon accumulated in the forest ecosystem $\left(\mathrm{ha}^{-1} \mathrm{yr}^{-1}\right)$ per kilogram of deposited nitrogen $\left(\mathrm{ha}^{-1} \mathrm{yr}^{-1}\right)$. The accumulation of carbon in terms of net ecosystem productivity (NEP) was between 27 and $84 \mathrm{~kg} \mathrm{Cha}^{-1} \mathrm{yr}^{-1}$ per $1 \mathrm{~kg} \mathrm{Nha}^{-1} \mathrm{yr}^{-1}$ (Table 4). All values in Table 4 are in good agreement with
Table 3. Relative increases (\%) of NPP and $\mathrm{CO}_{2}$ emission $\left(\mathrm{MgCha}^{-1}\right)$ at different levels of deposition of nitrogen compounds (AL - ambient level, I06 - increase of $6 \mathrm{~kg} \mathrm{Nha}^{-1} \mathrm{yr}^{-1}$, I1 - increase of $\left.12 \mathrm{~kg} \mathrm{Nha}^{-1} \mathrm{yr}^{-1}\right)$ and climatic scenarios ( $\mathrm{S}$ ambient climate, _C - climate change) for different climatic zones, in comparison to ambient level and ambient climate (AL_S).

\begin{tabular}{lrrrrr}
\hline & \multicolumn{5}{c}{ Simulation scenario } \\
\cline { 2 - 6 } & AL_C & I06_S & I06_C & I12_S & I12_C \\
\hline Net primary production & & & & & \\
Dankovskoe & 5.3 & 16.8 & 21.6 & 31.5 & 33.8 \\
Manturovskoe & 14.7 & 23.3 & 37.7 & 45.6 & 62.3 \\
Zheleznodorozhnoe & 20.1 & 11 & 33.3 & 22.1 & 45.4 \\
\hline Carbon dioxide emission & 31.9 & 22 & 37.2 & 24.8 & 52 \\
Dankovskoe & 16.8 & 12.8 & 31 & 25.4 & 43.4 \\
Manturovskoe & 20.5 & 6.6 & 28.9 & 13.3 & 37.4 \\
Zheleznodorozhnoe & 20.4 & & & &
\end{tabular}

suggestions in (Sutton et al., 2008) that sensitivity of $\mathrm{kg} \mathrm{C}$ per $\mathrm{kg} \mathrm{N}$ should be $50-75: 1$. It is also in agreement with data collected in Högberg (2012), which reported most of estimates to be in range between of $30-70 \mathrm{~kg} \mathrm{Cha}^{-1} \mathrm{yr}^{-1}$ per $1 \mathrm{~kg} \mathrm{Nha}^{-1} \mathrm{yr}^{-1}$ of atmospheric deposition.

There was a remarkable decrease of relative carbon accumulation per $\mathrm{kg} \mathrm{N}$ in different climatic zones from south (Dankovskoe forest area) to north (Zheleznodorozhnoe forest area) for almost all scenarios except AL_C.

The so-called "saturation effect" could be observed, where the value of relative carbon accumulation per kilogram of nitrogen decreased with the increase of the amount of deposited nitrogen. The relative carbon accumulation was higher in forest sites with more fertile soil and lower in forest sites with poor soil. On the other hand, the "saturation effect" was less remarkable in sites with poor soils. Finally, the relative accumulation of carbon was higher in sites with optimal moisture and decreased both with decrease and increase in moisture, more remarkably in the former case. Less carbon accumulation in forest sites with poor soils could be the result of lower productivity in such sites while the additional income of nitrogen might have a greater influence. Also, in extra dry and extra wet sites, the moisture is an important limiting factor, weakening the effect of nitrogen deposition. Similar effect has been found in Mäkipää et al. (1999). There is an assumption that when nitrogen is excessive in the ecosystem, then forest productivity starts to depend on other elements such as phosphorus, potassium etc (Butterbach-Bahl et al., 2011). But we do not take into account cycling of those elements in the model in use and we got this result despite of this assumption. Forest increments at the ambient level of nitrogen deposition decreased from south to north. A higher productivity gain was predicted for Dankovskoe and Manturovskoe forest areas (Fig. 3a,b) than for Zheleznodorozhnoe forest area (Fig. 3c). 
Table 4. Carbon accumulation, $\mathrm{kgCha}^{-1} \mathrm{yr}^{-1}$ per $1 \mathrm{kgN}$ $\mathrm{ha}^{-1} \mathrm{yr}^{-1}$ deposited with different levels of deposition of nitrogen compounds (AL - ambient level, I06 - increase of $6 \mathrm{~kg} \mathrm{~N}$ $\mathrm{ha}^{-1} \mathrm{yr}^{-1}, \mathrm{I} 12$ - increase of $12 \mathrm{~kg} \mathrm{Nha}^{-1} \mathrm{yr}^{-1}$ ) and climatic scenarios (_S - ambient climate, _C - climate change). Values for different forest sites and weighted average values for different forest areas.

\begin{tabular}{lrrrrrr}
\hline & \multicolumn{5}{c}{ Simulation scenario } \\
\cline { 2 - 7 } & AL_S & AL_C & I06_S & I06_C & I12_S & I12_C \\
\hline Forest site & 30.2 & 27.1 & 24.8 & 21.9 & 23.1 & 22.3 \\
A0 & 45.5 & 41.2 & 38.9 & 33.4 & 37.4 & 35.0 \\
A1 & 51.1 & 46.2 & 42.7 & 37.4 & 41.6 & 40.5 \\
A2 & 70.8 & 64.2 & 57.0 & 51.9 & 55.4 & 54.4 \\
A3 & 54.8 & 49.6 & 45.1 & 40.2 & 39.2 & 37.9 \\
A4 & 47.7 & 43.2 & 36.3 & 35.8 & 31.9 & 29.6 \\
A5 & 64.2 & 56.8 & 52.5 & 45.9 & 48.3 & 40.9 \\
B2 & 85.6 & 75.7 & 69.3 & 61.2 & 58.1 & 55.1 \\
B3 & 64.9 & 57.4 & 47.4 & 46.4 & 37.9 & 39.1 \\
B4 & 60.7 & 53.7 & 44.2 & 43.3 & 35.4 & 34.0 \\
B5 & 75.1 & 66.2 & 54.3 & 47.3 & 48.8 & 44.9 \\
C2 & 92.4 & 81.5 & 65.6 & 58.3 & 53.5 & 44.0 \\
C3 & 75.6 & 66.5 & 50.1 & 47.6 & 32.1 & 28.8 \\
C4 & 73.2 & 64.5 & 49.2 & 46.1 & 33.1 & 28.8 \\
C5 & 102.3 & 90.7 & 55.3 & 62.5 & 42.0 & 34.9 \\
D3 & 84.3 & 60.1 & 63.8 & 58.9 & 61.8 & 48.8 \\
\hline Forest area under study & & & & & & \\
Dankovskoe & 56.8 & 62.2 & 46.3 & 47.8 & 41.7 & 44.5 \\
Manturovkkoe & 47.9 & 55.5 & 31.5 & 36.3 & 27.1 & 29.2 \\
Zheleznodorozhnoe & & & & &
\end{tabular}

As we mentioned before there is a non-linear saturation in relation to nitrogen additions: the more nitrogen is added, the lower the sequestration of carbon. Climate change increases the relative sequestration of carbon except in southern Dankovskoe forest area. We will try to explain this exception later in the description of changes of species composition. The rate of carbon sequestration decreases from south to north. The lower forest growth is the main reason for this decrease.

\subsection{Dynamics of soil organic matter (SOM)}

Simulated soil carbon was $70-120 \mathrm{Mg} \mathrm{Cha}^{-1}$ for the ambient climate but about $20 \%$ lower $\left(60-100 \mathrm{Mg} \mathrm{Cha}^{-1}\right)$ under changed climate. This result is consistent with known experimental studies, where elevated temperature greatly increased soil respiration (Peterjohn et al., 1994), and where both elevated temperature and soil moisture resulted in accelerated SOM mineralization (Goncalves and Carlyle, 1994). It was shown at stand (Mäkipää et al., 1999) and global scale (Cao and Woodward, 1998; Jenkinson et al., 1991).

Climate change decreases SOM both in organic and mineral soil horizons (Fig. 4). Relative portion of SOM loss under climate change, in comparison to ambient climate, decreases from south to north (Table 5). The SOM in forest floor decreases faster. It corresponds to assumptions about acceleration of decomposition of SOM (i.e. Peterjohn et al., 1994).

The effect of increased nitrogen deposition on soil carbon pool was opposite to that of changed climate: carbon pool increased with higher nitrogen deposition (Fig. 4). This result is similar to that in Mäkipää et al. (1999). It could be easily observed from Table 5 that increased nitrogen input leads to an increase in SOM stock for all climatic zones. This result is in a good agreement with long-term forest nitrogen fertilization in Sweden and Finland (Hyvönen et al., 2008). Well-known measurements of increased organic floor thickness show that carbon sequestration in forest floor is a typical pattern for boreal forests in the absence of disturbances and with a long-term nitrogen deposition (Berg et al., 2009). Higher levels of nitrogen deposition result in a remarkable increase in the proportion of organic layer in the total SOM pool while the proportion of the mineral horizons in the total SOM stock decreased (Fig. 4). Climate change leads to the opposite effect. With the same level of nitrogen deposition, the proportion of organic layer in the total SOM stock under the climate change scenario was lower than under an ambient climate also for all areas under study.

Increased nitrogen deposition resulted in an increased growth rate of trees and, therefore, in an increased litter flow. The increased input of plant residues to soil resulted in increased SOM content at different levels of nitrogen deposition, mainly in the forest floor. Conversely, climate change led to a decrease in the relative SOM content in organic soil horizons (Fig. 4) and leads to increased carbon dioxide emissions. The relation between these opposite rates of SOM transformation actually depends on climatic zone. Maximal difference between these two acting factors is for south area and minimal is obtained at north. This result is in a good agreement with results of RECOGNITION project where effects of changing nitrogen deposition were showed to be smaller at high latitudes (Kahle et al., 2008). It is necessary to accentuate that RECOGNITION results have been obtained at stand scale, and our computer experiments are made at regional level.

\subsection{Dynamics of nitrogen stock}

The total amount of nitrogen in all ecosystems is growing, but it is reallocated in different ways in the more southern and more northern case studies (Fig. 5). In all cases nitrogen is accumulating in stands and maximal accumulation is obtained in intermediate climatic zone. In the north, leaching decreases the total nitrogen amount, mostly due to climate change, which speeds up decomposition processes and releases mobile nitrogen, which is then leached. 
Table 5. Soil carbon $\left(\mathrm{MgCha}^{-1}\right)$ in soil compartments at different levels of deposition of nitrogen compounds (AL - ambient level, I06 - increase of $6 \mathrm{~kg} \mathrm{Nha}^{-1} \mathrm{yr}^{-1}, \mathrm{I} 12$ - increase of $12 \mathrm{~kg} \mathrm{Nha}^{-1} \mathrm{yr}^{-1}$ ) and climatic scenarios ( $\mathrm{S}$ - ambient climate, _C - climate change) for different climatic zones.

\begin{tabular}{lrrrrrr}
\hline & \multicolumn{5}{c}{ Simulation scenario } \\
\cline { 2 - 7 } & AL_S & AL_C & I06_S & I06_C & I12_S & I12_C \\
\hline Forest floor & 14.7 & 8.4 & 19.1 & 9.0 & 23.0 & 11.3 \\
Dankovskoe & 19.1 & 12.3 & 24.3 & 16.4 & 31.7 & 20.9 \\
Manturovskoe & 15.3 & 11.1 & 17.0 & 12.0 & 19.4 & 13.6 \\
Zheleznodorozhnoe & & & & & & \\
\hline Mineral soil & 74.3 & 68.2 & 80.2 & 72.4 & 87.0 & 76.4 \\
Dankovskoe & 81.0 & 77.6 & 83.6 & 81.6 & 86.0 & 84.0 \\
Manturovskoe & 53.1 & 51.4 & 56.7 & 54.8 & 60.8 & 59.1 \\
Zheleznodorozhnoe & & & & & & \\
\hline
\end{tabular}

\subsection{Effect of climate change and nitrogen deposition on changes in species composition}

Additional nitrogen deposition also affected the species composition: the portion of deciduous tree species increased (Fig. 6). The most considerable changes were in the south. Here coniferous species are changing to parvifoliate and broadleaved trees. It leads to a decreasing rate of sequestration of carbon per nitrogen unit, because the nitrogen content in compartments of those species is much higher, and it is a reason for decreases in relative carbon sequestration. Moreover, climate changes accelerate species changes (forest succession). It is known that as climate changes tree species can change their positions within the mixed stand. Moreover, the geographical ranges of species may move northward, with the estimated migration rate being within the range of approximately 200 to $1000 \mathrm{~m} \mathrm{yr}^{-1}$ (Iverson and Prasad, 1998; Johnston et al., 2009; Pearson, 2006) or even $5000 \mathrm{~m} \mathrm{yr}^{-1}$ (Thuiller, 2007) due to the predicted increase in the mean annual temperature and associated alterations in precipitation patterns. The replacement of coniferous species by broadleaved ones has been shown using both paleoecological (Overpeck et al., 1991) and simulation methods (Iverson and Prasad, 1998, 2001; Sykes et al., 1996). It was also shown (Kellomäki and Kolström, 1992) that, while small temperature growth will increase the rates of decomposition and nitrogen cycling, large or prolonged temperature increases may cause a shift from coniferous to deciduous tree species. Since the rate of decomposition is higher in deciduous forests (because of both litter quality and site conditions), this may further increase availability of nitrogen, leading to increased productivity. This is why corresponding values of the relative carbon accumulation for Dankovskoe forest area given in Table 4 show a difference in relation to northern sites. Manturovskoe forest area has an intermediate position, and Zheleznodorozhnoe forest area does not demonstrate this effect because it has no deciduous species.

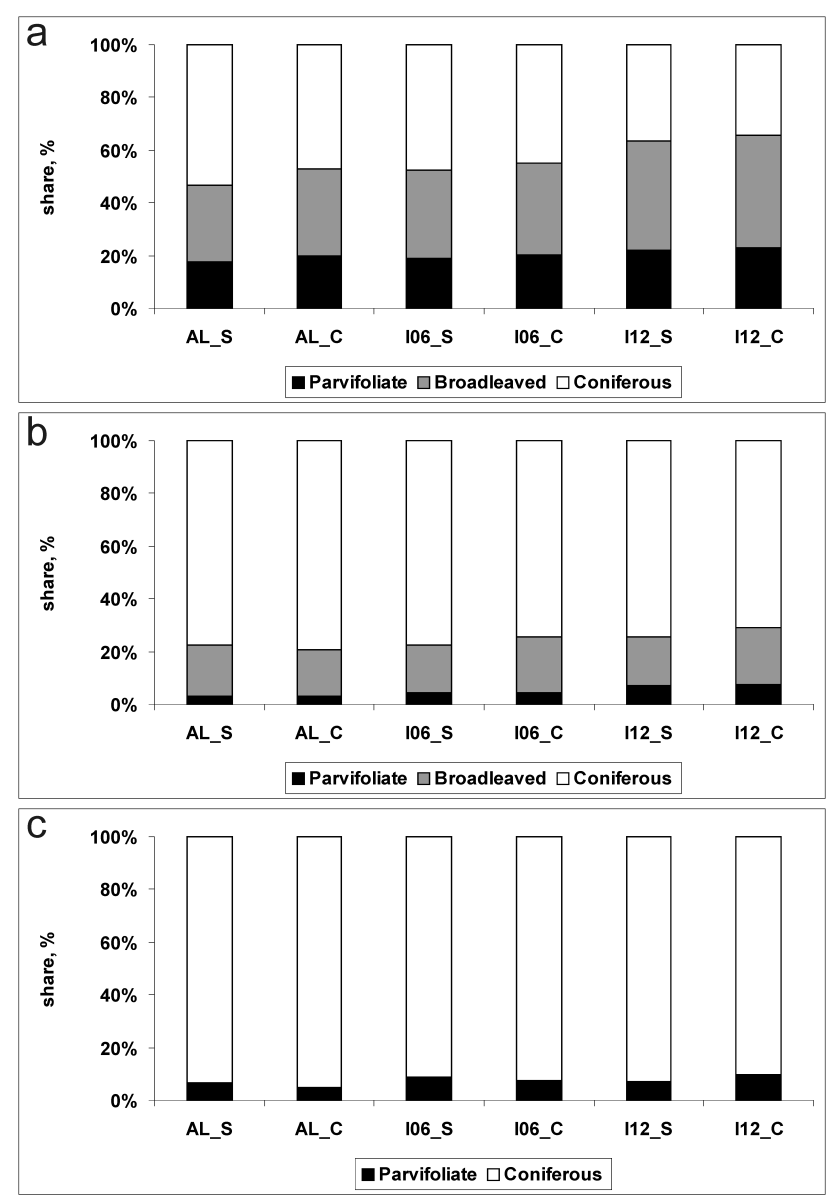

Fig. 6. Shares of different groups of tree species by the end of simulation with different levels of deposition of nitrogen compounds (AL - ambient level, I06 - increase of $6 \mathrm{~kg}[\mathrm{~N}] \mathrm{ha}^{-1} \mathrm{yr}^{-1}, \mathrm{I} 12$ increase of $12 \mathrm{~kg}[\mathrm{~N}] \mathrm{ha}^{-1} \mathrm{yr}^{-1}$ ) and climatic scenarios (_S - ambient climate, ${ }_{-} \mathrm{C}$ - climate change) for the different areas under study ((a) - Dankovskoe forest area, (b) - Manturovskoe forest area, (c) - Zheleznodorozhnoe forest area).

\section{Conclusions}

Interactive effects of climate change and atmospheric $\mathrm{N}$ deposition for forest ecosystems of European Russia confirm the hypothesis that both factors acting together have different influence on forest growth and carbon sequestration in forest soils in different climatic zones.

Our computer experiments have been done for three large sets of mixed stands which represent different types of forest sites and are located in three different climatic conditions. Our study shows that, in the forest lands of European Central Russia, warming leads to the following: (1) relative increases in forest productivity from south to north (the maximum increase is in the north (Table 3); (2) increases in carbon dioxide emission from the soil; (3) decreases in carbon in the forest floor; (4) increases in the proportion of broadleaved species (except the most northern area). 
Based on the simulations, we conclude that (1) nitrogen deposition plays a positive role in carbon sequestration in mixed forests in European Central Russia at the ambient average levels of nitrogen deposition; (2) it could play different relative roles in different climatic zones acting together with climate changes, as we suggested as a main hypothesis of our study. Nitrogen deposition has the most considerable impact on changes in NPP and changes in SOM stock in south in middle taiga sites. In northern sites NPP is increased first of all due to climate changes. Changes in forest SOM are expressed not significantly but have the same tendency. The same is for intermediate site in southern taiga. The most important consequence of interactive impacts of warming and nitrogen deposition is that they both change species composition for the benefit of deciduous species, which require more nitrogen for growth. It should be noted that we simulated forest natural development without any forest management and our results are applicable for the description of main tendencies in mixed forest development.

The causes of the above-described apparent synergic interactions of climate and nitrogen deposition could be studied further by detailed analysis of (1) different square distribution of forest sites with different soil richness (it was found that maximal changes at nitrogen deposition in NPP have been found in rich sites (Kahle et al., 2008) and our study areas are different in this distribution); (2) interspecific competition of main tree species in mixed forests at different levels of nitrogen deposition, which can lead to forest succession and changes in elements cycles; (3) detailed modelling of ground vegetation response to nitrogen deposition and their participation in elements cycling.

In conclusion, the effect of nitrogen deposition must be considered when evaluating forest carbon potentials under various future management and climate change scenarios.

Acknowledgements. This work was supported by RFBR grants 09-04-01209 and 12-04-01269, Programme 4 of RAS Presidium, and the FP7 Cooperative Project "Effects of climate change on air pollution impacts and response strategies for European ecosystems (ECLAIRE)", grant agreement no: 282910. We are grateful to Sergey Bykhovets for providing input data on climate. We also would like to thank Oleg Chertov and two anonymous reviewers for their insightful and useful comments.

Edited by: G. Billen

\section{References}

Alexeev, V. A. and Birdsey, R. A. (Eds.): Carbon Storage in Forests and Peatlands of Russia, USDA Forest Service Northeastern Research Station General Technical Report NE-244, 138 pp., 1998.

Bazilevich, N. I. and Titlyanova, A. A.: Biotic turnover on five continents: element exchange processes in terrestrial natural ecosystems, Novosibirsk, Publishing House SB RAS, 381 pp., 2008 (in Russian).
Berg, B., Johansson, M.-B., Nilsson, A., Gundersen, P., and Norell, L.: Sequestration of carbon in humus layers in Swedish forests - direct measurements, Can. J. Forest Res., 39, 962-975, doi:10.1139/X09-022, 2009.

Bhatti, J., Chertov, O., and Komarov, A.: Influence of Climate Change, Fire, Insect and Harvest on Carbon Dynamics for Jack Pine in Central Canada: Simulation Approach with the EFIMOD Model, The International Journal of Climate Change: Impacts and Responses, 1, 43-62, 2009.

Boisvenue, C. and Running, S. W.: Impacts of climate change on natural forest productivity - evidence since the middle of the 20th century, Glob. Change Biol., 12, 862-882, doi:10.1111/j.13652486.2006.01134.x, 2006.

Butterbach-Bahl, K., Gundersen, P., Ambus, P., Augustin, J., Beier, C., Boeckx, P., Dannermann, M., Sanchez Gimenso, B., Kiese, R., Kitzler, B., Ibrom, A., Rees, R. M., Smith, K. A., Stevens, C., Vesala, T., and Zechmeister-Boltenstern, S.: Nitrogen processes in terrestrial ecosystems, in: The European nitrogen assessment: sources, effects, and policy perspectives, edited by: Sutton, M. A., Howard, C. M., Erisman, J. W., Billen, G., Bleeker, A., Grennfelt, P., van Grinsven, H., and Grizzetti, B., Cambridge University Press, 99-125, 2011.

Bykhovets, S. S. and Komarov, A. S.: A simple statistical model of soil climate with a monthly step, Eurasian Soil Sci., 35, 392-400, 2002.

Callahan, H. S., Del Fierro, K., Patterson, A. E., and Zafar, H.: Impacts of elevated nitrogen inputs on oak reproductive and seed ecology, Glob. Change Biol., 14, 285-293, doi:10.1111/j.13652486.2007.01483.x, 2008.

Cannell, M. G. R.: World forest biomass and primary production data, Academic Press, London, 1982.

Cao, M. and Woodward, F. I.: Dynamic responses of terrestrial ecosystem carbon cycling to global climate change, Nature, 393, 249-252, doi:10.1038/30460, 1998.

Chertov, O. G., Komarov, A. S., Nadporozhskaya, M., Bykhovets, S. S., and Zudin, S. L.: ROMUL - a model of forest soil organic matter dynamics as a substantial tool for forest ecosystem modelling, Ecol. Model., 138, 289-308, doi:10.1016/S03043800(00)00409-9, 2001.

Chertov, O. G., Komarov, A. S., Kolstrom, M., Pikanen, S., Strandman, H., Zudin, S. L., and Kellomaki, S.: Modelling the longterm dynamics of populations and communities of trees in boreal forests based on competition on light and nitrogen, Forest Ecol. Manag., 176, 335-355, doi:10.1016/S0378-1127(02)00284-0, 2003.

Chertov, O., Komarov, A., Loukianov, A., Mikhailov, A., Nadporozhskaya, M., and Zubkova, E.: The use of forest ecosystem model EFIMOD for research and practical implementation at forest stand, local and regional levels, Ecol. Model., 194, 227-232, doi:10.1016/j.ecolmodel.2005.10.015, 2006.

Chertov, O., Bhatti, J., Komarov, A., Mikhailov, A., and Bykhovets, S.: Influence of climate change, fire and harvest on the carbon dynamics of black spruce in Central Canada, Forest Ecol. Manag., 257, 941-950, doi:10.1016/j.foreco.2008.10.038, 2009.

Chestnykh, O. V., Zamolodchikov, D. A., Utkin, A. I., and Korovin, G. N.: Distribution of organic carbon pools in soils of Russian Forests, Lesovedenie, 2, 13-21, 1999 (in Russian with English summary). 
Chestnykh, O. V., Zamolodchikov, D. G., and Utkin, A. I.: Reserves of biological carbon and nitrogen in soils of Russian Forest Fund, Lesovedenie, 4, 30-42, 2004 (in Russian with English summary).

Chestnykh, O. V., Lyzhin, V. A., and Koksharova, A. V.: The carbon reserves in litters of forests in Russia, Lesovedenie, 6, 114-121, 2007 (in Russian with English summary).

Cole, C. T., Anderson, J. E., Lindroth, R. L., and Waller, D. M.: Rising concentrations of atmospheric $\mathrm{CO}_{2}$ have increased growth in natural stands of quaking aspen (Populus tremuloides), Glob. Change Biol. 16, 2186-2197, doi:10.1111/j.13652486.2009.02103.x, 2010.

Coops, N. C. and Waring, R. H.: Assessing forest growth across southwestern Oregon under a range of current and future global change scenarios using a process model, 3-PG, Glob. Change Biol. 7, 15-29, doi:10.1046/j.1365-2486.2001.00385.x, 2001.

De Vries, W., Solberg, S., Dobbertin, M., Sterba, H., Laubhahn, D., Reinds, G. J., Nabuurs, G.-J., Gundersen, P., and Sutton, M. A.: Ecological implausible carbon response?, Nature, 451, E1-E3, doi:10.1038/nature06579, 2008.

Ellsworth, D. S., Thomas, R., Crous, K. Y., Palmroth, S., Ward, E., Maier, C., Delucia, E., and Oren, R.: Elevated $\mathrm{CO}_{2}$ affects photosynthetic responses in canopy pine and subcanopy deciduous trees over 10 years: a synthesis from Duke FACE, Glob. Change Biol., 18, 223-242, doi:10.1111/j.13652486.2011.02505.x, 2012.

Goncalves, J. L. M. and Carlyle, J. C.: Modelling the influence of moisture and temperature on net nitrogen mineralization in a forested sandy soil, Soil Biol. Biochem., 26, 1557-1564, doi:10.1016/0038-0717(94)90098-1, 1994.

Högberg, P.: What is the quantitative relation between nitrogen deposition and forest carbon sequestration?, Glob. Change Biol., 18, 1-2, doi:10.1111/j.1365-2486.2011.02553.x, 2012.

Hyvönen, R., Perrson, T., Andersson, S., Olsson, B., Ågren, G. I., and Linder, S.: Impact of long-term nitrogen addition on carbon stocks in trees and soils in northern Europe, Biogeochemistry, 89, 121-137, doi:10.1007/s10533-007-9121-3, 2008.

Iverson, L. R. and Prasad, A. M.: Predicting abundance of 80 tree species following climate change in the Eastern United States, Ecol. Monogr., 68, 465-485, 1998.

Iverson, L. R. and Prasad, A. M.: Potential changes in Tree Species Richness and Forest Community Types following Climate Change, Ecosystems, 4, 186-199, doi:10.1007/s10021001-0003-6, 2001.

Janssens, I. A., Dieleman, W., Luyssaert, S., Subke, J.-A., Reichstein, M., Ceulemans, R., Ciais, P., Dolman, A. J., Grace, J., Matteucci, G., Papale, D., Piao, S. L., Schulze, E.-D., Tang, J., and Law, B. E.: Reduction of forest soil respiration in response to nitrogen deposition, Nat. Geosci., 3, 315-322, doi:10.1038/ngeo844, 2010.

Jenkinson, D. S., Adams, D. E., and Wild, A.: Model estimates of $\mathrm{CO}_{2}$ emissions from soil in response to global warming, Nature, 351, 304-306, doi:10.1038/351304a0, 1991.

Johnson, D. W. and Curtis, P. S.: Effects of forest management on soil C and N storage: meta analysis, Forest Ecol. Manag., 140, 227-238, doi:10.1016/S0378-1127(00)00282-6, 2001.

Johnston, M., Campagna, M., Gray, P., Kope, H., Loo, J., Ogden, A., O’Neill, G. A., Price, D. T., and Williamson, T. B.: Vulnerability of Canada's Tree Species to Climate Change and Management Options for Adaptation: An Overview for Policy Makers and Practitioners, Canadian Council of Forest Ministers, Ottawa, Ontario, 44 pp., 2009.

Kahle, H.-P., Karjalainen, T., Schuck, A., Ågren, G., Kellomäki, S., Mellert, K., Prietzel, J., Rehfuess, K. E., and Spiecker, H. (Eds.): Causes and Consequences of Forest Growth Trends in Europe - Results of the RECOGNITION Project, EFI Research Report, 21, Brill, Leiden, Boston, 262 pp., 2008.

Karjalainen, T., Spiecker, H., and Laroussinie, J. (Eds.): Causes and Consequences of Accelerating Tree Growth in Europe, EFI Proceedings 27, European Forest Institute, 286 pp., 1999.

Kellomäki, S. and Kolström, M.: Simulation of tree species composition and organic matter accumulation in Finnish boreal forests under changing climatic conditions, Vegetatio, 102, 4768, doi:10.1007/BF00031703, 1992.

Kirschbaum, M. U. F.: The temperature dependence of soil organic matter decomposition, and the effect of global warming on soil organic C storage, Soil. Biol. Biochem, 27, 753-760, doi:10.1016/0038-0717(94)00242-S, 1994.

Knorr, M., Frey, S. D., and Curtis, P. S.: Nitrogen additions and litter decomposition: A meta-analysis, Ecology, 86, 3252-3257, doi:10.1890/05-0150, 2005.

Komarov, A., Chertov, O., Zudin, S., Nadporozhskaya, M., Mikhailov, A., Bykhovets, S., Zudina, E., and Zoubkova, E.: EFIMOD 2 - a model of growth and cycling of elements in boreal forest ecosystems, Ecol. Model., 170, 373-392, doi:10.1016/S0304-3800(03)00240-0, 2003.

Komarov, A. S., Chertov, O. G., Nadporozhskaya, M. A., Priputina, I. V., Bykhovets, S. S., Larionova, A. A., Grabarnik, P. Ya., Zudin, S. L., Mikhailov, A. V., Zubkova, E. V., Zudina, E. V., Shanin, V. N., Andrienko, G., Andrienko, N., Martynkin, A. V., Mohren, F., Abakumov, E. V., Lukjanov, A. M., Kubasova, T. S., Bhatti, J., Shaw, C., Apps, M., Bobrovskiy, M. V., Khanina, L. G., Smirnov, V. E., and Glukhova, E. M.: Modelling Organic Matter Dynamics in Forest Ecosystems, Nauka Publishing, Moscow, 392 pp., ISBN 5-02-034053-7, 2007 (in Russian).

Kurganova, I., Lopes de Gerenyu, V., Rozanova, L., Sapronov, D., and Myakshina, T.: Annual and seasonal $\mathrm{CO}_{2}$ fluxes from Russian southern taiga soils, Tellus B, 55, 338-344, doi:10.1034/j.1600-0889.2003.00047.x, 2003.

Kurz, W. A., Dymond, C. C., White, T. M., Stinson, G., Shaw, C. H., Rampley, G. J., Smyth, C., Simpson, B. N., Neilson, E. T., Trofymow, J. A., Metsaranta, J., and Apps, M. J.: CBMCFS3: a model of carbon-dynamics in forestry and land-use change implementing IPCC standards, Ecol. Model., 220, 480504, doi:10.1016/j.ecolmodel.2008.10.018, 2009.

Larocque, G. R., Bhatti, J. S., Boutin, R., and Chertov, O.: Uncertainty analysis in carbon cycle models of forest ecosystems: Research needs and development of a theoretical framework to estimate error propagation, Ecol. Model., 219, 400-412, doi:10.1016/j.ecolmodel.2008.07.024, 2008.

Liebig, J. V.: Die Chemie in ihrer Aswendung auf Agricultur und Physiologie, Aufl. Braunshweig, 5, 506 pp., 1843 (in German).

Lloyd, J. and Taylor, J. A.: On the temperature dependence of soil respiration, Funct. Ecol., 8, 315-323, doi:10.2307/2389824, 1994.

Lopatin, E., Kolström, T., and Spiecker, H.: Determination of forest growth trends in Komi Republic (northwest Russia): combination of tree-ring analysis and remote sensing data, Boreal Environ. Res., 11, 341-353, 2006. 
Magnani, F., Mencuccini, M., Borghetti, M., Berbigier, P., Berninger, F., Delzon, S., Grelle, A., Hari, P., Jarvis, P. G., Kolari, P., Kowalski, A. S., Lankreijer, H., Law, B. E., Lindroth, A., Loustau, D., Manca, G., Moncrieff, J. B., Rayment, M., Tedeschi, V., and Valentini, R.: The human footprint in the carbon cycle of temperate and boreal forests, Nature, 447, 848-850, doi:10.1038/nature05847, 2007.

Mäkipää, R., Karjalainen, T., Pussinen, A., and Kellomäki, S.: Effects of climate change and nitrogen deposition on the carbon sequestration of a forest ecosystem in the boreal zone, Can. J. Forest Res., 29, 1490-1501, doi:10.1139/x99-123, 1999.

Marklund, L. G.: Biomass functions for pine, spruce and birch in Sweden, Department of Forest Survey, Swedish University of Agricultural Sciences, Report no. 45, 73 pp., 1988 (in Swedish).

Melillo, J. M., McGuire, A. D., Kicklighter, D. W., Moore, B., Vorosmarty, C. J., and Schloss, A. L.: Global climate change and terrestrial net primary production, Nature, 363, 234-239, doi:10.1038/363234a0, 1993

Mikhailov, A. V., Komarov, A. S., and Chertov, O. G.: Simulation of the carbon budget for different scenarios of forest management, Eurasian Soil Sci., 37, 93-96, 2004.

Mitchell, T. D., Carter, T. R., Jones, P. D., Hulme, M., and New, M.: A comprehensive set of high resolution grids of monthly climate for Europe and the globe: the observed record (1901-2000) and 16 scenarios (2001-2100), Tyndall Centre for Climate Change Research, Norwich, Working Paper No. 55, 25 pp., 2004.

Moore, D. J. P., Aref, S., Ho, R. M., Pippen, J. S., Hamilton, J. G., and De Lucia, E. H.: Annual basal area increment and growth duration of Pinus taeda in response to eight years of free-air carbon dioxide enrichment, Glob. Change Biol., 12, 1367-1377, doi:10.1111/j.1365-2486.2006.01189.x, 2006.

Myneni, R. B., Keeling, C. J., Tucker, C., Asrar, G., and Nemani, R. R.: Increased plant growth in the northern high latitudes from 1981 to 1991, Nature, 386, 698-702, doi:10.1038/386698a0, 1997.

Nadelhoffer, K. J., Emmett, B. A., Gundersen, P., Kjonaas, O. J., Koopmans, C. J., Schleppi, P., Tietema, A., and Wright, R. F.: Nitrogen deposition makes a minor contribution to carbon sequestration in temperate forests, Nature, 398, 145-148, doi:10.1038/18205, 1999.

Overpeck, J. T., Bartlein, P. J., and Webb, T. I.: Potential magnitude of future vegetation change in eastern North America: comparisons with the past, Science, 254, 692-695, doi:10.1126/science.254.5032.692, 1991.

Palosuo, T., Peltoniemi, M., Mikhailov, A. V., Komarov, A. S., Faubert, P., Thürig, E., and Lindner, M.: Projecting effects of intensified biomass extraction with alternative modelling approaches, Forest Ecol. Manag., 255, 1423-1433, doi:10.1016/j.foreco.2007.10.057, 2008.

Pearson, R. G.: Climate change and the migration capacity of species, Trends Ecol. Evol., 21, 111-113, doi:10.1016/j.tree.2005.11.022, 2006.

Peterjohn, W. T., Melillo, J. M., Steudler, P. A., Newkirk, K. M., Bowles, F. P., and Aber, J. D.: Responses of trace gas fluxes and $\mathrm{N}$ availability to experimentally elevated soil temperatures, Ecol. Appl., 4, 617-625, doi:10.2307/1941962, 1994.

Prescott, C. E.: Does nitrogen availability control rates of litter decomposition in forests?, Plant Soil, 168-169, 83-88, doi:10.1007/BF00029316, 1995
Pussinen, A., Karjalainen, T., ,Mäkipää, R., Valsta, L., and Kellomäki, S.: Forest carbon sequestration and harvests in Scots pine stand under different climate and nitrogen deposition scenarios, Forest Ecol. Manag., 158, 103-115, doi:10.1016/S03781127(00)00675-7, 2002.

Ramirez, K. S., Craine, J. M., and Fierer, N.: Nitrogen fertilization inhibits soil microbial respiration regardless of the form of nitrogen applied, Soil Biol. Biochem., 42, 2336-2338, doi:10.1016/j.soilbio.2010.08.032, 2010.

Rustad, L. E., Campbell, J. L., Marion, G. M., Norby, R. J., Mitchell, M. J., Hartley, A. E., Cornelissen, J. H. C., and Gurevitch, J.: A meta-analysis of the response of soil respiration, net nitrogen mineralization, and aboveground plant growth to experimental ecosystem warming, Oecologia, 126, 543-562, doi:10.1007/s004420000544, 2001.

Schulze, E. D. (Ed.): Carbon and Nitrogen Cycling in European Forest Ecosystems, Ecol. Stud., Vol. 142, Heidelberg, Springer Verlag, 500 pp., 2000.

Shanin, V. N., Komarov, A. S., Mikhailov, A. V., and Bykhovets, S. S.: Modelling carbon and nitrogen dynamics in forest ecosystems of Central Russia under different climate change scenarios and forest management regimes, Ecol. Model., 222, 2262-2275, doi:10.1016/j.ecolmodel.2010.11.009, 2011.

Shanin, V. N., Komarov, A. S., and Bykhovets, S. S.: Simulation modelling for sustainable forest management: a case-study, Procedia Environmental Sciences, 13, 535-549, doi:10.1016/j.proenv.2012.01.044, 2012.

Shaw, C., Chertov, O., Komarov, A., Bhatti, J., Nadporozskaya, M. Apps, M., Bykhovets, S., and Mikhailov, A.: Application of the forest ecosystem model EFIMOD 2 to jack pine along the Boreal Forest Transect Case Study, Can. J. Soil Sci., 86, 171-185, doi:10.4141/S05-079, 2006.

Shvidenko, A., Schepaschenko, D., Nilsson, S., and Bouloui, Yu.: Semi-empirical models for assessing biological productivity of Northern Eurasian forests, Ecol. Model., 204, 163-179, doi:10.1016/j.ecolmodel.2006.12.040, 2007.

Spiecker, H.: Growth trends in European forests - Do we have sufficient knowledge?, in: Causes and consequences of accelerating tree growth in Europe, edited by: Karjalainen, T., Spiecker, H., and Laroussinie, O., Eur. Forest Inst. Proc., 27, 157-169, 1999.

State report "On the state and Environmental Protection of the Russian Federation in 1997": National Centre for Environmental Programs of the Russian Federation, State Committee for Environmental Protection, Moscow, 608 pp., 1998.

State report "On the state and Environmental Protection of the Russian Federation in 2010": Ministry of Natural Resources and Environmental Protection of the Russian Federation, Autonomous non-commercial organization "Centre for International Projects”, Moscow, 571 pp., 2011.

Sutton, M. A., Simpson, D., Levy, P. R., Smith, R. I., Reis, S., Van Oijen, M., and De Vries, W.: Uncertainties in the relationship between atmospheric nitrogen deposition and forest carbon sequestration, Glob. Change Biol., 14, 2057-2063, doi:10.1111/j.13652486.2008.01636.x, 2008

Sutton, M. A., Howard, C. M., Erisman, J. W., Billen, G., Bleeker, A., Grennfelt, P., van Grinsven, H., and Grizzetti, B. (Eds.): The European nitrogen assessment: sources, effects, and policy perspectives, Cambridge University Press, 664 pp., ISBN 978-1107-00612-6, 2011. 
Sykes, M. T., Prentice, I. C., and Cramer, W.: A bioclimatic model for the potential distributions of north European tree species under present and future climates, J. Biogeogr., 23, 203-233, 1996.

Thomas, R. Q., Canham, C. D., Weathers, K. C., and Goodale, C. L.: Increased tree carbon storage in response to nitrogen deposition in the US, Nat. Geosci., 3, 13-17, doi:10.1038/ngeo721, 2010.

Thuiller, W.: Biodiversity: Climate change and the ecologist, Nature, 448, 550-552, doi:10.1038/448550a, 2007.

Townsend, A. R., Brasswell, B. H., Holland, E. A., and Penner, J. E.: Spatial and temporal patterns in terrestrial carbon storage due to deposition of fossil fuel nitrogen, Ecol. Appl., 6, 806-814, doi:10.2307/2269486, 1996.

Verkerk, P. J. H., Eggers, J., Lindner, M., Korotkov, V. N., and Zudin, S. L.: Impact of wood demand and management regime on forest development and carbon stocks in Kostroma region, in: Proceedings of the international scientific conference on modern problems of sustainable forest management, inventory and monitoring of forests, St. Petersburg, Russia, 29-30 November 2006, 370-379, 2006.
Vetter, M., Wirth, C., Böttcher, H., Churkina, G., Schulze, E.D., Wutzler, T., and Weber, G.: Partitioning direct and indirect human-induced effects on carbon sequestration of managed coniferous forests using model simulations and forest inventories, Glob. Change Biol., 11, 810-827, doi:10.1111/j.13652486.2005.00932.x, 2005.

Vorobjev, D. P.: Forest types in European part of the USSR, Academy of Sciences of USSR, Kiev, 452 pp., 1953 (in Russian).

Zaboeva, I. V.: Soils and land resources of Komi Autonomous Soviet Socialist Republic, Komi book publishing house, Syktyvkar, USSR, 343 pp., 1975 (in Russian).

Zamolodchikov, D. G.: Systems of assessment and forecast of carbon sinks in forest ecosystems, Sustainable Forest Management (Moscow), 4, 15-22, 2011 (in Russian).

Zamolodchikov, D. G., Grabovsky, V. I., Korovin, G. N., and Kurz, W. A.: Assessment and projection of carbon budget in forests of Vologda region using the Canadian model CBM-CFS, Lesovedenie, 6, 3-14, 2008 (in Russian with English summary). 